\title{
MANAGEMENT OF DIABETES MELLITUS THROUGH AYURVEDA
}

\author{
Minal P. Mawale ${ }^{1 *}$, Sanket V. Pajai ${ }^{2}$
}

${ }^{1}$ Assistant Professor, Bhausaheb Mulak Ayurveda College and Hospital, Nagpur, Maharashtra, India

${ }^{2}$ Assistant Medical Officer, B.M.C. Mumbai, Maharashtra, India

Received on: 10/08/14 Revised on: 20/09/14 Accepted on: 09/10/14

\author{
*Corresponding author \\ Dr. Minal P. Mawale, Bhausaheb Mulak Ayurved College \& Hospital, KDK Campus, Great Nag Road, Nandanwan, Nagpur-440009 Maharashtra, \\ India E-mail: mawaleminal@gmail.com \\ DOI: $10.7897 / 2277-4343.055127$
}

\section{ABSTRACT}

Around the world, Diabetes, Obesity and Cardiovascular diseases are affecting the health and well being of hundreds of millions of people. These diseases are no longer confined to developed world as millions of people in developing countries are adopting westernized lifestyle and are being affected by these diseases mainly Diabetes Mellitus. It is a chronic medical condition associated with abnormally high levels of sugar and can last a life time. Over time, diabetes mellitus can lead to blindness, kidney failure, nerve damage and atherosclerosis, leading to strokes, coronary heart diseases, and other blood vessel diseases in the body. Modern system of medicine is successful in preventing diseases of infective origin but it is difficult to prevent lifestyle diseases alone with it. As Ayurveda is recognized as foremost life science and describes ways to prevent and manage lifestyle disorders. Diabetes mellitus can be prevented and better managed by principles of Ayurveda.

Keywords: lifestyle diseases, complications of Diabetes mellitus, Ayurveda principles.

\section{INTRODUCTION}

The incidence of lifestyle diseases like Diabetes mellitus (DM), Hypertension and Obesity associated with cardiovascular diseases are high on risk, with rapid economic development and increased westernization of lifestyle. In the past few decades, prevalence of these diseases has reached alarming proportions among Indians. Diabetes mellitus comprises a group of common metabolic disorders that share the phenotype of hyperglycemia. Several distinct types of Diabetes exist and are caused by a complex interaction of genetics, environmental factors and lifestyle choices. The metabolic deregulation associated with DM causes secondary path physiologic changes in multiple organ systems that impose a tremendous burden on the individual and on the healthcare system if proper preventive measures are not taken. ${ }^{1}$ Ayurveda considers health and disease both as the products of food and life style. A positive life style and wholesome food promote positive health and prevent diseases. It is in tune with this concept that Ayurveda evolved intensive life style care and advocated adoptions of Swasthavritta and Sadvritta in all spheres of life. Such codes of life and health conducts relate to personal, social as well as spiritual dimensions of an individual. It is amazing that thousands of years ago, Ayurveda conceived the significance of the errors of life style in causation of all kinds of diseases, both physical and mental, now which is increasingly considered as the principal cause of many illness prevalent today. Ayurveda provides better solutions in the form of proper dietary management, lifestyle advises panchakarma like detoxification and bio-purification procedures, medicaments, and yoga and rejuvenation therapies for better management in Diabetes mellitus.

\section{Classification of Diabetes Mellitus}

Type 1 Diabetes. (Beta cell destruction, usually leading to absolute insulin deficiency)

$\circ \quad$ Immune mediated

$\circ \quad$ Idiopathic

Type 2 Diabetes. (characterized by variable degrees of insulin resistance, impaired insulin secretion and increased glucose production)

Other types of Diabetes mellitus

- Genetic defects of insulin action.

- Genetic defects of B cells.

- Exocrine diseases of Pancreas.

$\circ \quad$ Endocrinopathies.

○ Drug induced.

- Gestational. $^{2}$

\section{Diagnosis of Diabetes Mellitus}

Patients complains of symptoms suggesting of Diabetes

- Test urine and ketones.

- Measure random blood sugar/ fasting blood sugar.

Indications for oral glucose tolerance test

FBS: $6.1-7.0 \mathrm{mmol} / 1$ (110-126 mg/dL)

Random BS: $7.8-11.0 \mathrm{mmol} / 1(140-199 \mathrm{mg} / \mathrm{dL})^{3}$

\section{Symptoms of Diabetes Mellitus}

Thirst

Polyuria, Nocturia

Tiredness, Fatigue

Recent changes in weight

Blurring of vision

Pruritis vulvae

Predilection for sweet food

Mood changes, irritability

Difficulty in concentrating. ${ }^{4}$ 


\section{Complications of Diabetes Mellitus}

Acute complications

- Diabetes Keratoacidosis (DKA)

- Hyperglycemic Hyperosmolar State (HHS)

Chronic complications

- Micro vascular: - Eye disease Neuropathy

- Retinopathy

- Nephropathy

- Macular Oedema

- Macro vascular: - Coronary Artery Disease

- Peripheral Vascular Disease

- Cerebral Vascular Disease. ${ }^{5}$

\section{Management of Diabetes Mellitus \\ Dietary/lifestyle modification \\ Oral anti-diabetic agents \\ Insulin $^{6}$}

To reach these goals, physician should identify a target level of glycemic control for each patient. Provide the patient with the educational and pharmacologic resources necessary to reach this level, monitor complications.

\section{Drawbacks of modern therapy for DM}

As with any therapy, the benefits of efforts directed towards glycemic control must be weighed against the risk of treatment. Side effects of intensive treatment include- increased frequency of hypoglycemia, weight gain, increased economic cost. In Diabetes Control and Complications Trial (DCCT) individuals with the greatest weight gain exhibited increases LDL cholesterol and Triglycerides as well as increase in B.P. this could increase the risk of CVD. ${ }^{7}$

\section{Diabetes Mellitus in Ayurveda}

Diabetes is described as Prameha in Ayurvedic classics. Prameha which has been correlated with Diabetes Mellitus has become a global problem in spite of advances in modern science.

\section{Etiology}

The main causes of Prameha (diabetes) are lack of exercise and improper food habits. Excess food intake, snigdha and guru gunatmak foods are the primal cause of this disease eg fish, curd, new rice, sweet items, butter, ghee, milk, alcohol, udad dal are good examples. Foods that increase kapha, medhas and moothra are the etiological factors for Prameha. ${ }^{8}$ Except theses, no exercise, sleeping in day time; laziness is also causative factors of Pramaeha.

\section{Types of Prameha}

For the management of this disease - Prameha (diabetes) can be listed in two categories:

1. Apatarpana uthaja prameha describing the lean diabetic and

2. Santarpana uthaja prameha relating the obese diabetic.
Etiological classification of (Prameha) diabetic patients

1. Sahaja prameha (congenital)

2. Apathyanimittaja prameha (due to over eating and poor habits $)^{9}$

These have further been classified in to twenty sub categories in all the three classics of Ayurveda. Kaphaja and Pittaja Prameha has been sub classified in to ten types and six types respectively. Vataja prameha has been sub classified in to four types depending up on dhatu being excreted through urine.

\section{Characteristics of Prameha}

The characteristic features of all types of prameha are prabhootha and aavila mootrata and medo dushti lakshanas - excessive urination and turbidity in urine and symptoms of vitiated medodhatu. ${ }^{10}$

\section{Complications of Prameha}

Excessive thirst, loose motions, fever, burning sensation, weakness, anorexia, boils over the skin are some complications of Prameha, if not treated properly. ${ }^{11}$

\section{Role of Ayurveda in Prameha}

According to Acharya Charak, Prameha is santarpanja vyadhi so it should be treated by Vaman, Virechan and Raktamokshan. ${ }^{12}$ According to Acharya Charak Vyayam, Upwas, Dhoompan and Swedana like activities, Vyoshadi saktu are beneficial for prameha patient. $^{13}$ Acharya Sushruta, had mentioned Prameha as Apathyanimittaj Vyadhi and hence advised to avoid certain food such as Souvirak, Tushodak, Shukta, Mairey, Sura, Asav, excessive milk, curd, oil, ghee, flour, and meat of the animals which live in water or near water. Acharya Sushruta then mentioned pathya ahar for the same as Shali, Shashthi Chawal, Yava, Godhuma, Kulattha, Moong dal, Oil from Sarso and Atasi seeds, Tikta and Kashay Rasatmak vegetables and Jangal Mamsa ${ }^{14}$. Acharya Sushruta had mentioned many decoctions according to Dosha pradhanya. They are as follow: For Kaphaj Prameha: Paribhadra, Agnimantha, Neem, Chitrak, Khadir, Patha, Agaru, Haridra, Daruharidra, Saptaparna, Durwa, Karanj, Arjun, Triphala, Aragwadh, etc. For Pittaj Prameha: Shalsar Gana, Nyagrodhadi Gana, Manjistha, Chandan, Guduchi,etc. For Vataj Prameha: Kustha, Kutaj, Kutaki, Agnimanth, chitrak, Shishapa, Khadir, Kramuk, Tinduk, Kapitth, Shirish, Palash, etc. ${ }^{15}$ Apart from above decoctions certain Rasoushadhi like Vasanta Kusumakara Rasa Brhat Vangesvara Rasa, Svarna Vanga, Prameha Cintamani Rasa, Guduchyadi Yoga, Bhudatryadi Yoga, Nisha Triphala Yoga, Silajita, Dhanvantara Ghrita Dadimadya Ghrita, Chaandraprabha Vati, Gokshuradi Guggul, etc can be use effectively.

\section{Yoga and Pranayama}

Regular practice of Matsyendrasana, Vajrasanstha Yogmudra, Pacchimottanasana, Sarvangasana, Halasana like asanas, Nadi shuddhi Pranayama, Bhastrika and Bhramari Pranayama and Kapal bhati can prevent and improve the condition of Pramehi. 


\section{CONCLUSION}

So it can be concluded that Ayurveda provides better solutions in the form of proper dietary management, lifestyle advises panchakarma like detoxification and biopurification procedures, medicaments, yoga and rejuvenation therapies for better management in Prameha.

\section{REFERENCES}

1. Dan Longo, Anthony Fauci, Dennis Kasper, Stephen Hauser et al. Harrison's principles of internal medicine. $16^{\text {th }} \mathrm{ed}$. New York, Mc Graw Hill companies; 2005. p. 2152.

2. Dan Longo, Anthony Fauci, Dennis Kasper, Stephen Hauser et al. Harrison's principles of internal medicine. $16^{\text {th }}$ ed. New York, Mc Graw Hill companies; 2005. p. 2153.

3. Doon, Nicholas A editor, Davidson's, principles and practice of medicine, Sir Stanley. 20 ${ }^{\text {th }}$ ed. Philadelphia, Churchil Livingstone Elsevier; 2006. p. 817.

4. Doon, Nicholas A editor, Davidson's, principles and practice of medicine, Sir Stanley. $20^{\text {th }}$ ed. Philadelphia, Churchil Livingstone Elsevier; 2006. p. 818.

5. Dan Longo, Anthony Fauci, Dennis Kasper, Stephen Hauser et al. Harrison's principles of internal medicine. $16^{\text {th }} \mathrm{ed}$. New York, Mc Graw Hill companies; 2005. p. 2158, 2161.

6. Doon, Nicholas A editor, Davidson's, principles and practice of medicine, Sir Stanley. $20^{\text {th }}$ ed. Philadelphia, Churchil Livingstone Elsevier; 2006. p. 818.

7. Dan Longo, Anthony Fauci, Dennis Kasper, Stephen Hauser et al. Harrison's principles of internal medicine. $16^{\text {th }}$ ed. New York, Mc Graw Hill companies; 2005. p. 2178.

8. Acharya Vidyadhar Shukla and Prof Ravidutta Tripathi editor. Charaksamhita of Agnivesh, elaborated by Charak and Drudhbal with Vaidyamanorama Hindi commentary, Reprint. Delhi, Chaukhamba Sanskrit Pratishthan; 2000. p. 502.

9. Dr Anantram Sharma editor. Sushrut Samhita of Sushrut edited with Sushrutmaharshini Hindi commentary, Reprint. Varanasi, Chaukhamba Surbharati Prakashan; 2001. p. 267.

10. Dr Anantram Sharma editor. Sushrut Samhita of Sushrut edited with Sushrutmaharshini Hindi commentary, reprint. Varanasi, Chaukhamba Surbharati Prakashan; 2001. p. 503.

11. Acharya Vidyadhar Shukla and Prof Ravidutta Tripathi editor Charaksamhita of Agnivesh, elaborated by Charak and Drudhbal with Vaidyamanorama Hindi commentary, Reprint. Delhi, Chaukhamba Sanskrit Pratishthan; 2000. p. 511.

12. Acharya Vidyadhar Shukla and Prof Ravidutta Tripathi editor. Charaksamhita of Agnivesh, elaborated by Charak and Drudhbal with Vaidyamanorama Hindi commentary, Reprint. Delhi, Chaukhamba Sanskrit Pratishthan; 2000. p. 317.

13. Acharya Vidyadhar Shukla and Prof Ravidutta Tripathi editor. Charaksamhita of Agnivesh, elaborated by Charak and Drudhbal with Vaidyamanorama Hindi commentary, Reprint. Delhi, Chaukhamba Sanskrit Pratishthan; 2000. p. 317.

14. Dr Anantram Sharma editor. Sushrut Samhita of Sushrut edited with Sushrutmaharshini Hindi commentary, Reprint. Varanasi, Chaukhamba Surbharati Prakashan; 2001. p. 268.

15. Dr Anantram Sharma editor. Sushrut Samhita of Sushrut edited with Sushrutmaharshini Hindi commentary, Reprint. Varanasi, Chaukhamba Surbharati Prakashan; 2001. p. 269

\section{Cite this article as:}

Minal P. Mawale, Sanket V. Pajai. Management of Diabetes mellitus through Ayurveda. Int. J. Res. Ayurveda Pharm. 2014;5(5):622-624 http://dx.doi.org/10.7897/2277-4343.055127 